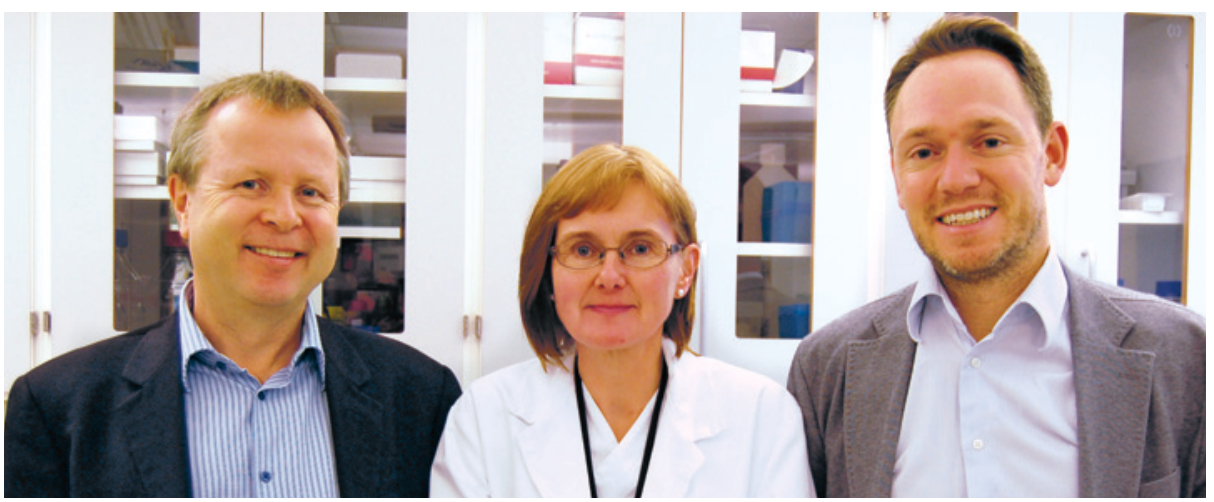

Fra venstre Torbjørn Omland, Gunnhild Kravdal og Helge Røsjø. Foto privat

\title{
Remodellering kan forklare troponinstigning
}

Myokardremodellering kan forklare høye konsentrasjoner av troponin I og $\mathrm{T}$ i blodbanen hos pasienter med kronisk hjertesykdom, ifølge norsk studie.

Målinger av hjertespesifikk troponin I og $\mathrm{T}$ i blodet brukes for å stille diagnosen hjerteinfarkt. Det er imidlertid usikkert om troponinnivået $\mathrm{i}$ blodbanen kan stige ved myokardiskemi som er antatt ikke å indusere celledød (reversibel iskemi). En studie fra Akershus universitetssykehus bidrar nå til å kaste lys over dette (1).

Konsentrasjon av troponin I og $\mathrm{T}$ i blodbanen ble målt med høysensitive metoder hos 198 pasienter henvist til nukleærmedisinsk hjerteundersøkelse med arbeidstest (sykkelbelastning). Deltakere med reversibel myokardiskemi hadde høyere nivåer av troponin I og $\mathrm{T}$ i blodet før arbeidsbelastningen, men mindre økning i konsentrasjon etter arbeidsbelastningen enn deltakere uten myokardiskemi.

- Resultatene støtter dermed ikke hypotesen at reversibel myokardiskemi gir frisetting av troponinmolekyler til blodbanen, sier førsteforfatter Helge Røsjø. - Vi fant derimot en nær sammenheng mellom variabler assosiert med strukturelle endringer av hjertemuskulaturen, såkalt myokardremodellering, og høye troponinnivåer. Myokardremodellering kan derfor være forklaringen på høye konsentrasjoner av troponin I og $\mathrm{T}$ i blodbanen hos pasienter med kronisk hjertesykdom. Sammenhengen mellom myokardremodellering og økte troponinkonsentrasjoner er tidligere også vist hos pasienter med alvorlig aortastenose og i den generelle populasjonen i studier fra samme gruppe. Dette passer med at høye troponin T-konsentrasjoner er en uavhengig prediktor for hjertesviktutvikling og død hos pasienter med stabil koronarsykdom, men ikke nytt hjerteinfarkt, sier han.

- Leger bør være klar over sammenhengen mellom myokardremodellering og høye troponinkonsentrasjoner, siden troponinmålinger nå utføres på store pasientgrupper i sykehus og i økende grad også utenfor sykehus. En pasient med høy troponinkonsentrasjon uten klassiske symptomer på akutt koronarsyndrom eller typisk stigning og/eller fall i troponinkonsentrasjon vil kunne ha nytte av en ekkokardiografisk undersøkelse av hjertets anatomi og funksjon, sier Røsjø.

\section{Forskergruppen}

Studien ACE 1 Study er ledet av Helge Røsjø og Torbjørn Omland i Cardiothoracic Research Group ved Medisinsk divisjon, Akershus universitetssykehus, i nært samarbeid med Gunnhild Kravdal, Seksjon for nukleærmedisin og biokjemi ved samme sykehus. Pirouz Badr, Hjertemedisinsk avdeling, Akershus universitetssykehus, og Arne Didrik Høiseth, Ragnhild Røysland og Marit Jørgensen, alle Cardiothoracic Research Group, deltok også.

Cardiothoracic Research Group ved Akershus universitetssykehus kombinerer grunnforskning med kliniske studier på store pasientgrupper. Målsettingen er å utvikle skreddersydd behandling til pasienter med hjertedysfunksjon. Gruppen har særlig studert biologiske markører på hjertefunksjon og testet og validert bruken av etablerte hjertemarkører som troponiner og B-type natriuretiske peptider.

Studien var støttet økonomisk av Akershus universitetssykehus og Abbott Diagnostics, som ga tilgang til en prototypetest for høysensitiv troponin I.

\section{Erlend Hem}

erlend.hem@medisin.uio.no

Tidsskriftet

\section{Litteratur}

1. Røsjø H, Kravdal G, Høiseth AD et al. Troponin I measured by a high-sensitivity assay in patients with suspected reversible myocardial ischemia: data from the Akershus Cardiac Examination (ACE) 1 Study. Clin Chem 2012; 58: 1565-73.

\section{Ordforklaring}

Høysensitiv troponinmetode: Det finnes nå analysemetoder for troponin med bedre sensitivitet enn tidligere. En høysensitiv troponintest oppfyller følgende to kriterier: Den kvantifiserer troponinkonsentrasjonen i majoriteten (> 50 \%) av antatt hjertefriske individer og har tilfredsstillende analytisk presisjon i konsentrasjoner under 99-prosentilen hos friske individer.

Nukleærmedisinsk hjerteundersøkelse med arbeidstest (sykkelbelastning): Ved å injisere en lav dose radioaktivt stoff intravenøst og måle opptaket i hjertemuskelen ved hjelp av et gammakamera får man et semikvantitativt mål på blodgjennomstrømmingen. Bilder tatt like etter arbeidsbelastning blir sammenliknet med bilder tatt 3-4 timer senere for å avdekke

reversibel myokardiskemi (lavere opptak like etter arbeidsbelastning).

Myokardremodellering: Samlebetegnelse på strukturelle forandringer i hjertemuskulaturen som venstre ventrikkel-vekst (hypertrofi) og endringer i mikroarkitektur (celler og bindevev). Gir endret relaksasjon av hjertemuskulaturen, kan påvirke kontraktiliteten og er en risikofaktor for hjertesviktutvikling og død.

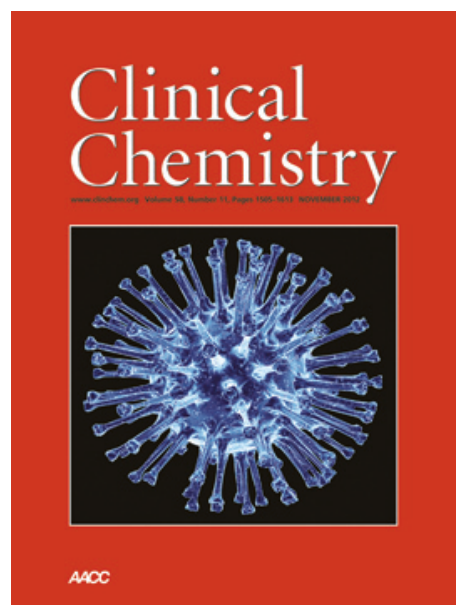

Artikkelen ble publisert i novemberutgaven 2012 av tidsskriftet Clinical Chemistry (http://www.clinchem.org), som er det høyest rangerte tidsskriftet innen klinisk kjemi 